Published in final edited form as:

ACS Appl Mater Interfaces. 2016 August 31; 8(34): 21848-21860. doi:10.1021/acsami.6b01194.

\title{
In Vitro Multitissue Interface Model Supports Rapid Vasculogenesis and Mechanistic Study of Vascularization across Tissue Compartments
}

\author{
Kevin P. Buno ${ }^{\dagger}$, Xuemei Chen ${ }^{\ddagger} \S$, Justin A. Weibel ${ }^{\ddagger}, \S$, Stephanie N. Thiede ${ }^{\dagger}$, Suresh V.

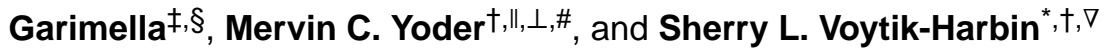 \\ tWeldon School of Biomedical Engineering, Purdue University, West Lafayette, Indiana 47907, \\ United States \\ ¥School of Mechanical Engineering, Purdue University, West Lafayette, Indiana 47907, United \\ States \\ §Birck Nanotechnology Center, Purdue University, West Lafayette, Indiana 47907, United States \\ "Department of Pediatrics, Indiana University School of Medicine, Indianapolis, Indiana 46202, \\ United States \\ ${ }^{\perp}$ Herman B Wells Center for Pediatric Research, Indiana University School of Medicine, \\ Indianapolis, Indiana 46202, United States \\ \#Department of Biochemistry and Molecular Biology, Indiana University School of Medicine, \\ Indianapolis, Indiana 46202, United States \\ ${ }^{\nabla}$ Department of Basic Medical Sciences, Purdue University, West Lafayette, Indiana 47907, \\ United States
}

\begin{abstract}
A significant challenge facing tissue engineers is the design and development of complex multitissue systems, including vascularized tissue-tissue interfaces. While conventional in vitro models focus on either vasculogenesis (de novo formation of blood vessels) or angiogenesis (vessels sprouting from existing vessels or endothelial monolayers), successful therapeutic vascularization strategies will likely rely on coordinated integration of both processes. To address this challenge, we developed a novel in vitro multitissue interface model in which human endothelial colony forming cell (ECFC)-encapsulated tissue spheres are embedded within a surrounding tissue microenvironment. This highly reproducible approach exploits biphilic surfaces
\end{abstract}

\footnotetext{
*Corresponding Author: harbins@ @urdue.edu. Phone: (765) 496-6128. Address: Martin C. Jischke Hall of Biomedical Engineering, Room 3033, 206 South Martin Jischke Drive, West Lafayette, IN 47907-2032, U.S.A.

Supporting Information

The Supporting Information is available free of charge on the ACS Publications website at DOI: 10.1021/acsami.6b01194.

Superhydrophobic surface sterilization, measurement of sphere area, decision tree used for categorizing vessel morphologies formed in vitro, and demonstration of hollow lumen formation of ECFC-derived vessels (PDF)

Author Contributions

The manuscript was written through contributions of all authors. All authors have given approval to the final version of the manuscript.

Notes

The authors declare no competing financial interest.
} 
(nanostructured surfaces with distinct superhydrophobic and hydrophilic regions) to (i) support tissue compartments with user-specified matrix composition and physical properties as well as cell type and density and (ii) introduce boundary conditions that prevent the cell-mediated tissue contraction routinely observed with conventional three-dimensional monodispersion cultures. This multitissue interface model was applied to test the hypothesis that independent control of cellextracellular matrix (ECM) and cell-cell interactions would affect vascularization within the tissue sphere as well as across the tissue-tissue interface. We found that high-cell-density tissue spheres containing $5 \times 10^{6} \mathrm{ECFCs} / \mathrm{mL}$ exhibit rapid and robust vasculogenesis, forming highly interconnected, stable (as indicated by type IV collagen deposition) vessel networks within only 3 days. Addition of adipose-derived stromal cells (ASCs) in the surrounding tissue further enhanced vasculogenesis within the sphere as well as angiogenic vessel elongation across the tissue-tissue boundary, with both effects being dependent on the ASC density. Overall, results show that the ECFC density and ECFC-ASC crosstalk, in terms of paracrine and mechanophysical signaling, are critical determinants of vascularization within a given tissue compartment and across tissue interfaces. This new in vitro multitissue interface model and the associated mechanistic insights it yields provide guiding principles for the design and optimization of multitissue vascularization strategies for research and clinical applications.

\section{Graphical abstract}

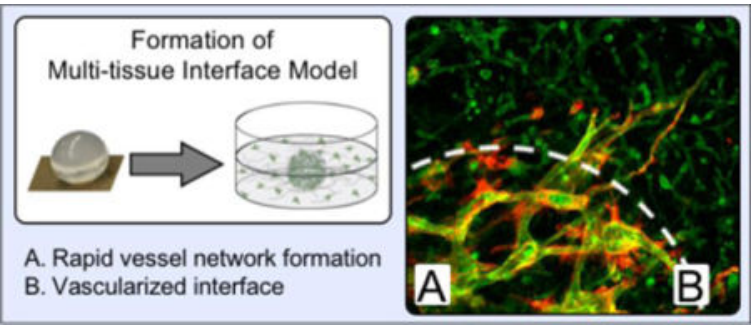

\section{Keywords}

collagen oligomers; vascularization; multitissue interface; adipose-derived stromal cells (ASCs); endothelial colony forming cells (ECFCs); mechanobiology; tissue engineering

\section{INTRODUCTION}

A significant challenge facing tissue engineers is the design and functional assembly of complex multitissue systems, including vascularized tissue-tissue interfaces. ${ }^{1,2}$ Such systems are typically composed of multiple cell types arranged and organized with boundaries or within gradients of extracellular matrix (ECM) components to perform specific functional roles. ${ }^{3}$ Moreover, incorporating functional vasculature within such multitissue systems is essential to their scalability, long-term tissue survivability, and effective integration with host tissues upon implantation. ${ }^{4}$ It is now recognized that a complex interplay of biochemical and biophysical cues is involved in tissue morphogenesis, ${ }^{5}$ and new design approaches to support the construction and optimization of vascularized tissue-tissue interfaces are needed. 
To create complex, vascularized tissue-engineered constructs, the guiding mechanisms of blood vessel formation, maturation, and stabilization must first be understood.

Neovascularization, as occurs in vivo during embryonic development and throughout adult life, involves two primary processes, namely, vasculogenesis and angiogenesis. ${ }^{5,6}$

Vasculogenesis represents the de novo self-assembly of vessel networks by endothelial cell precursors, making it ideally suited for tissue engineering strategies. Angiogenesis involves the sprouting and elongation of new vessels from pre-existing vasculature, a process necessary for facilitating functional anastomosis, or hook-up, between the vascularized tissue construct and the host vasculature.

A number of critical steps and mechanisms underlying vasculogenesis and angiogenesis have been defined using various three-dimensional (3D) in vitro vascularization models. For example, angiogenic capillary sprouting is observed when endothelial cells (ECs) are cultured as a monolayer atop the surface of a 3D ECM substrate ${ }^{7}$ or sandwiched between substrate layers. ${ }^{89}$ Capillary sprouting also occurs from aortic rings, ${ }^{10}$ microvessels, ${ }^{11}$ ECcoated microbeads, ${ }^{12}$ or EC aggregates/spheroids ${ }^{13,14}$ embedded within substrates.

Collectively, angiogenesis involves invasion of physiologically relevant substrates, such as interstitial fibrillar type I collagen or fibrin, by activated ECs of existing vessels or monolayers; this requires limited matrix proteolysis, proliferation, migration, and lumen formation and stabilization. ${ }^{15}$ In contrast, in vitro models of vasculogenesis involve monodispersion of ECs or their progenitors, where individual cells are homogeneously distributed within a 3D substrate (Figure 1A,B). ${ }^{16-18}$ Here, programmed events associated with vasculogenesis include vacuole formation, vacuole coalescence to form multicellular lumens, and vessel maturation and stabilization. ${ }^{19}$ These $3 \mathrm{D}$ in vitro models, together with corroborating in vivo evidence, show that vessel morphogenesis is modulated by a complex series of events involving cell-cell, cell-ECM, growth factor, and morphogen signaling. ${ }^{20}$

While these 3D in vitro models have provided mechanistic insight into vascularization processes, they are limited in their ability to define critical design parameters necessary for vascularization of tissue-engineered constructs and, more importantly, vascularization across tissue-tissue interfaces. For example, tissue construct contraction, which results from cellmatrix traction forces, is often associated with high cell densities and/or low-mechanicalintegrity substrates. ${ }^{21,22}$ Such contraction events affect vessel morphogenesis outcomes by altering the mechanical boundary conditions of the tissue construct, ${ }^{21,23}$ compromising the overall vessel network morphology, tissue histology, and scalability. Improved definition and standardization of critical design parameters, including cell type, cell seeding density, medium composition, substrate composition, substrate physical properties, and mechanical boundary conditions, are needed to ensure robust and reproducible functional performance of vascularized tissue-engineered constructs for both research and clinical applications. ${ }^{16,24}$

The present study features a design approach that utilizes, for the first time, biphilic wettability surfaces having hydrophilic regions patterned onto a superhydrophobic background to direct the formation of spherical cell-collagen tissues. Such spherical cellcollagen tissues can be readily integrated into a second tissue for creation of a multitissue interface in vitro (Figure 1C,D). This approach enables independent specification of each tissue's interstitial collagen-fibril ECM and resident cell populations, including type and 
density. This new culture model was applied to test a hypothesis that independent control of cell-ECM and cell-cell interactions would affect vessel morphogenesis within a component tissue as well as across the tissue-tissue interface. An essential element of the design approach is the application of type I collagen oligomers, which represent a soluble collagen formulation that self-assembles to form collagen-fibril matrices with higher-order interfibril associations. As such, the supramolecular assembly of oligomers supports the creation of collagen-fibril matrices with a broad range of structural and mechanical properties (specified by fibril density and matrix stiffness) beyond those that can be achieved with conventional collagen monomers, atelocollagen, and telocollagen. ${ }^{25-28}$ Furthermore, embedding oligomer-based tissue spheres within an oligomer-based surrounding tissue facilitates the creation of a tissue-tissue interface that maintains stability even in the presence of high cell densities, which may be necessary to replicate certain physiological conditions.

Previously, oligomer collagen-fibril matrices have been shown to provide the necessary mechanobiological cues to induce and guide monodispersions of endothelial colony forming cells (ECFCs) to form lumenized vessel networks stabilized by a basement membrane both in vitro and in vivo. ${ }^{26,29} \mathrm{In}$ the present work, the multitissue interface method is applied to culture ECFCs at unprecedented densities, thereby accelerating vessel morphogenesis to within 3 days. This culture model also demonstrates that the ECFC density and crosstalk between ECFCs and adipose-derived stromal cells (ASCs) across a tissue-tissue interface play critical roles in not only determination of the vessel network morphology but also stabilization of vessels formed within and across tissue compartments. Controlling and optimizing relevant design features associated with multitissue interfaces, specifically the structural and mechanical features of the collagen-fibril matrix as well as the cell composition and density, may assist the development of vascularized tissue interfaces for a diverse range of tissue engineering applications.

\section{METHODS}

\section{Fabrication of Biphilic Surfaces with Spatially Nonuniform Wettability}

Superhydrophobic surfaces were fabricated on Si substrates using a metal-assisted chemical etching method. ${ }^{30}$ The surface was first etched with 5\% HF aqueous solution for $3 \mathrm{~min}$ to produce a hydrogen-terminated substrate and then immersed into an aqueous solution containing 4.8 $\mathrm{M} \mathrm{HF}$ and $5 \mathrm{mM} \mathrm{AgNO}_{3}$ for 1 min to create a uniform layer of $\mathrm{Ag}$ nanoparticles. The surface was rinsed with water to remove surplus $\mathrm{Ag}^{+}$and then immersed in an etchant composed of $4.8 \mathrm{M} \mathrm{HF}$ and $0.4 \mathrm{M} \mathrm{H}_{2} \mathrm{O}_{2}$ for $30 \mathrm{~min}$. After etching, the $\mathrm{Si}$ substrate was washed repeatedly with water and immersed in dilute $\mathrm{HNO}_{3}\left(1: 2 \mathrm{HNO}_{3} /\right.$ deionized water) for $30 \mathrm{~min}$ to dissolve the Ag catalyst. As a result of this process, $\mathrm{Si}$ nanowires were grown uniformly across the substrate. To render the surface superhydrophobic, the sample was silanized through immersion in a $1 \mathrm{mM} n$-hexane solution of $1 \mathrm{H}, 1 \mathrm{H}, 2 \mathrm{H}, 2 \mathrm{H}$-perfluorooctyltrichlorosilane for $1 \mathrm{~h}$ followed by heat treatment at $\sim 150^{\circ} \mathrm{C}$ on a hot plate for $1 \mathrm{~h}$. The static apparent contact angle and roll-off angle of the asfabricated surface were measured to be $\sim 165^{\circ}$ and $<1^{\circ}$, respectively, using a ramé-hart (Succasunna, NJ) model 590 goniometer; while a spherical droplet was formed upon 
deposition on the surface, these highly nonwetting characteristics prevented reproducible attachment and positioning of droplets on the surface.

In order to facilitate the formation and adhesion of spherical collagen and cell-collagen droplets on the surface, laser-assisted surface treatment was used to selectively create hydrophilic regions on the superhydrophobic background. An array of dots $(0.9 \mathrm{~mm}$ diameter dots with a center-to-center spacing of $4.5 \mathrm{~mm}$ ) was generated on the surface using a commercial $\mathrm{CO}_{2}$ laser-engraving system (PLS6MW, Universal Laser Systems, Inc., Scottsdale, AZ; $75 \mathrm{~W}$, laser wavelength $=10.6 \mu \mathrm{m}$ ). The system was used to inscribe the desired pattern on the substrate by raster-scanning the laser beam across the surface at a speed of $0.2 \mathrm{~m} / \mathrm{s}$ with 400 pulses per inch. The laser irradiation rapidly increases the local temperature and removes the superhydrophobic surface-coating material, generating hydrophilic dots to which droplets can attach.

The biphilic surfaces were exposed to two different sterilization techniques, including an autoclave $\left(121^{\circ} \mathrm{C}, 15 \mathrm{~atm}, 15 \mathrm{~min}\right)$ and $80 \%$ ethanol diluted in Milli-Q water (15 min). Surfaces that received the $80 \%$ ethanol treatment were rinsed thrice in sterile phosphatebuffered saline (PBS) and then air-dried. Contact angle measurements of water droplets (5 $\mu \mathrm{L})$ were taken before and after the sterilization treatments. Surfaces were tested in triplicate $(n=3)$, and the results were compared using a paired $t$ test.

\section{Preparation of Type I Collagen Oligomers}

Type I collagen oligomers were acid-solubilized from the dermis of market-weight pigs and lyophilized for storage as described previously. ${ }^{26}$ The oligomer formulation was standardized on the basis of molecular composition as well as polymerization capacity according to ASTM International standard F3089-14. ${ }^{31}$ Here the polymerization capacity is defined by the matrix shear storage modulus, $G^{\prime}$ (in Pa), as a function of oligomer concentration in the polymerization reaction. Each collagen solution was diluted with $0.01 \mathrm{~N}$ $\mathrm{HCl}$ to achieve the desired concentration and neutralized with $10 \times \mathrm{PBS}$ and $0.1 \mathrm{~N} \mathrm{NaOH}$ to achieve $\mathrm{pH}$ 7.4. ${ }^{32}$ Neutralized solutions were kept on ice prior to induction of polymerization by warming to $37^{\circ} \mathrm{C}$.

\section{Validation of Collagen Sphere Geometry and Reproducibility}

Type I collagen oligomers were diluted in $0.01 \mathrm{~N} \mathrm{HCl}$ and neutralized to stiffness values of 0, 200, and $1000 \mathrm{~Pa}$, which correspond to final oligomer concentrations of 0.0, 1.4, and 2.9 $\mathrm{mg} / \mathrm{mL}$, respectively. Air-displacement (Pipetman, Gilson Inc., Middleton, WI) and positivedisplacement (Microman, Gilson Inc.) pipettes were used to dispense oligomer at specified volumes of 5,10 , and $15 \mu \mathrm{L}$ onto the hydrophilic spots of the biphilic surface, resulting in sphere formation (Figure 2). For each experimental group, triplicate spheres were formed ( $n$ $=3$ ). Sphere volumes were measured from goniometer images, and the sphere geometry was characterized by the droplet height-to-width aspect ratio (ImageJ, NIH, Bethesda, MD):

$$
\text { aspect ratio }=\frac{H_{\text {sphere }}}{W_{\text {sphere }}}
$$


where $H_{\text {sphere }}$ and $W_{\text {sphere }}$ represent the height and width of the oligomer sphere, respectively. An ideal sphere would have an aspect ratio of 1 ; the amount of reduction below 1 indicates the degree of sphere distortion.

\section{Cell Culture}

Human ECFCs were isolated from umbilical cord blood and cultured as described previously. ${ }^{33}$ Low-passage human ASCs were grown according to the manufacturer's instructions (Zen-Bio, Research Triangle Park, NC). Both ECFCs and ASCs were propagated in complete endothelial cell growth medium (EGM-2, Lonza, Walkersville, MD) supplemented with $10 \%$ fetal bovine serum (HyClone, ThermoFisher Scientific, Waltham, MA). Cells were grown and maintained in a humidified environment of $5 \% \mathrm{CO}_{2}$ in air at $37^{\circ} \mathrm{C}$. ECFCs and ASCs were used in experiments at passages between 8 and 13 .

\section{Preparation of 3D Monodispersion and Multitissue Interface Tissue Constructs}

For the monodispersion format (Figure 1A,B), ECFCs were suspended in neutralized oligomer at a density of $0.5 \times 10^{6}, 2 \times 10^{6}$, or $5 \times 10^{6}$ cells $/ \mathrm{mL}$. The oligomer-cell suspension was aliquoted into a 48 -well plate $(250 \mu \mathrm{L} /$ well $)$ and subsequently polymerized at $37^{\circ} \mathrm{C}$ for $15 \mathrm{~min}$.

For the multitissue interface format (Figure 1C,D), $5 \mu \mathrm{L}$ aliquots of oligomer-cell suspension were pipetted onto the biphilic surfaces to create spheres, which were polymerized for $10 \mathrm{~min}$ at $37^{\circ} \mathrm{C}$. Next, the oligomer-cell suspension for the surrounding tissue was pipetted into 48 -well tissue culture plates at $250 \mu \mathrm{L} /$ well. A single polymerized oligomer-cell sphere was immediately placed in the center of each well, and the surrounding tissue was polymerized for $15 \mathrm{~min}$ at $37^{\circ} \mathrm{C}$. The volumes of the sphere and surrounding tissue microenvironment were selected such that the sphere was not in contact with the upper (liquid-air interface) and lower (cultureware) surfaces, ensuring uniform and highly reproducible tissue-tissue interactions and mechanophysical properties across the sphere surface area. All of the tissue constructs were cultured in complete EGM-2 medium in an incubator $\left(5 \% \mathrm{CO}_{2}, 37^{\circ} \mathrm{C}\right)$ with daily medium replacements. All of the experimental groups were tested in triplicate $(n=3)$.

\section{Assessment of Sphere and Overall Tissue Contraction}

To monitor qualitative changes in the embedded sphere and tissue construct volume as a function of cell seeding density and time, macroscopic top-view images of the 48-well plate were taken at $0,24,48$, and $72 \mathrm{~h}$. The sphere boundary was identified in each image, and the sphere cross-sectional area was calculated using ImageJ. After 3 days of culture, tissues were rinsed thrice in PBS, fixed in 3\% paraformaldehyde, and rinsed thrice again in 1× PBS. A volume displacement method was used to quantitatively measure the final tissue volume. Triplicate wells containing tissue constructs, along with three empty wells, were carefully filled with PBS. Next, the supernatant (PBS) from each sample was weighed using an analytical balance (BP 210 D, Sartorius, Elk Grove, IL). The known mass of the supernatant and the density of water at $21.5^{\circ} \mathrm{C}(0.9979 \mathrm{~g} / \mathrm{mL})$ were used to calculate the supernatant volume, $V_{\text {supernatant }}$, which represents the volume in the well not occupied by tissue. The 
volume calculated for the empty wells represents the total volume of each well, $V_{\text {well }}$. Subtracting $V_{\text {supernatant }}$ from $V_{\text {well }}$ gives a measure of tissue volume:

$$
V_{\text {tissue }}=V_{\text {well }}-V_{\text {supernatant }}
$$

From initial tissue volumes, $V_{i}$, of 250 and $255 \mu \mathrm{L}$ for the matrix-only and multitissue interface methods, respectively, the final tissue volume percentages were calculated:

$$
\text { final tissue volume } \%=\frac{V_{\text {tissue }}}{V_{i}} \times 100 \%
$$

\section{Immunostaining of 3D Tissue Constructs}

Tissue constructs were fixed in 3\% paraformaldehyde after 3 days of culture, permeabilized with $1 \%$ Triton $\mathrm{X}-100$, blocked with $1 \%$ bovine serum albumin, and stained with rabbit antihuman collagen type IV (ab6581, Abcam, Cambridge, MA) overnight at $4{ }^{\circ} \mathrm{C}$. The constructs then were rinsed with PBS and incubated with goat anti-rabbit-Alexa Fluor 633 conjugate (A-21070, Life Technologies, Carlsbad, CA) overnight at $4{ }^{\circ} \mathrm{C}$. After rinsing, constructs were counterstained with fluorescein isothiocyanate (FITC)-conjugated Ulex europaeus agglutinin 1 (UEA-1) lectin (L9006, Sigma-Aldrich, St. Louis, MO) and phalloidin (A22283, Molecular Probes, Eugene, OR) to stain the endothelial cell membrane and actin cytoskeleton, respectively.

\section{D Vessel Morphology Analysis}

For 3D qualitative analysis, tissue constructs were imaged using an Olympus FluoView FV-1000 confocal system adapted to an inverted microscope (IX81, Olympus Corporation, Tokyo, Japan). Image stacks were collected from one to three locations within each of the three independent tissue constructs per experimental group. All of the image files were imported into MATLAB (The MathWorks, Natick, MA) to create projections of each stack. Confocal reflection microscopy was used to visualize the collagen-fibril microstructure. ${ }^{34}$

For quantitative vessel morphometric analysis, a confocal image stack $(635.9 \mu \mathrm{m} \times 635.9$ $\mu \mathrm{m} \times 100 \mu \mathrm{m}$ ) was collected from the tissue sphere within each of the three independent tissue constructs per experimental group $(n=3)$. Image files were imported into Imaris (Bitplane, Concord, MA) for 3D reconstruction and analysis. Briefly, an isosurface was created and split into individual surface objects that were characterized by a set of geometric parameters including sphericity, ellipticity (prolate or oblate), ellipsoid axis length, and volume. Objects were then classified as a quiescent cell, short vessel, small vessel network (SVN), extensive vessel network (EVN), or other using the decision tree shown in Figure S1 in the Supporting Information. Objects with volumes less than $2000 \mu \mathrm{m}^{3}$ were regarded as debris and not considered in the morphological profile analysis. The volumes of objects classified as a short vessel, SVN, and EVN were summed to calculate the total vessel volume, which was used to calculate the vessel volume percentage of the entire imaged volume. 


\section{Quantification of Alignment of Collagen Fibrils and Cells}

Confocal reflection and fluorescence image volumes were used to determine the collagen fibril and cell orientations, respectively. Image volumes $(1309 \mu \mathrm{m} \times 436 \mu \mathrm{m} \times 30 \mu \mathrm{m})$ were captured in such a way that their length was oriented parallel to the normal line of the sphere. Each image volume was then segmented into thirds lengthwise to determine the orientation as a function of distance from the tissue-tissue interface. The angular direction was calculated using an ImageJ fast Fourier transform algorithm. The absolute values of all orientation angles were then divided by 90 to create a normalized alignment parameter with values of 0 and 1 representing orientations tangent (parallel) and normal (perpendicular) to the sphere surface. Two image volumes within each of three replicate constructs were analyzed.

\section{Statistical Analysis}

Statistical analyses were performed using statistical analysis software (SAS, Cary, NC). Unless otherwise stated, comparisons were made using one-way analysis of variance (ANOVA) with a Tukey posthoc test. A critical global $p$ value of 0.05 was used.

\section{RESULTS AND DISCUSSION}

\section{Biphilic Surfaces Reproducibly Form Collagen and Tissue Spheres}

Superhydrophobic surfaces are characterized by a large water droplet contact angle $\left(>150^{\circ}\right.$; see Figure 2A) and low contact angle hysteresis $\left(<10^{\circ}\right)$, resulting in spherical droplets that roll off the surface even when it is tilted at a very slight angle. In the present work, biphilic surfaces consisting of hydrophilic regions patterned onto a superhydrophobic surface supported the highly reproducible formation of variously sized tissue spheres composed of polymerized collagen-fibril matrices in the presence and absence of cells (Figure 2B,C). Patterning the superhydrophobic surface with small hydrophilic spots was necessary to facilitate solution deposition and prevent free rolling of spheres. Spots with a diameter of 0.9 $\mathrm{mm}$ preserved a high contact angle of greater than $150^{\circ}$, creating highly spherical tissue construct geometries.

A full factorial experimental design was performed to quantify the effects of oligomer matrix stiffness (as specified by the oligomer concentration) and volume $(5,10$, or $15 \mu \mathrm{L}$ ) on the tissue sphere geometry and reproducibility. For a given target tissue sphere volume, the measured sphere volume delivered by an air-displacement pipet was inversely related to the collagen-fibril matrix stiffness (oligomer concentration) (Figure 3A). The measured tissue sphere volumes for $1000 \mathrm{~Pa}$ oligomer, representing the highest-viscosity solution, were roughly $73 \%, 78 \%$, and $84 \%$ of the specific target volumes of 5,10 , and $15 \mu \mathrm{L}$, respectively. The use of a positive-displacement pipet dramatically improved the volume delivery accuracy and precision. In fact, when a positive-displacement pipet was used to create 1000 Pa spheres, the accuracy was at least $87 \%$ and the precision was $1.9 \%$ or better for all volumes tested. Unlike air-displacement pipettes, which use a compressible dead-air volume to move the fluid, positive-displacement pipettes use an incompressible piston to move the fluid. This direct contact enhances the accuracy and precision, especially for viscous liquids. Finally, although gravity effects caused an inverse relationship between the sphere aspect 
ratio and the measured volume, the sphere aspect ratios were greater than 0.8 for all volumes and matrix stiffness values tested (Figure 3B). Taken together, the results demonstrate that the oligomer tissue sphere volume and geometry can be reproduced with high precision and accuracy.

\section{Multitissue Interface Format Prevents Cell-Mediated Tissue Contraction of High-Cell- Density Tissues}

A number of researchers, including our group, have shown that conventional monodispersion cultures of ECs or their progenitors within type I collagen or fibrin matrices undergo vasculogenesis. ${ }^{21,29,35-37}$ The extent of vessel network formation, as well as their maturation and stability, depends on specific microenvironment conditions, including matrix composition and physical properties, ${ }^{21,29,25,38,39}$ medium composition, ${ }^{40}$ type of $\mathrm{EC},{ }^{21}$ and addition of accessory cells. ${ }^{19,39}$ The extent of vessel formation was also shown to be positively correlated with the EC seeding density; ${ }^{41}$ however, seeding densities of $1 \times 10^{6}$ cells $/ \mathrm{mL}$ or lower are routinely used to avoid tissue construct contraction. Tissue contraction depends on the combination of cell density and type,${ }^{21}$ matrix type and associated physical properties, ${ }^{42-44}$ and physical boundary conditions. ${ }^{22,43}$ Culture surface coating with glutaraldehyde, polyethylenimine, or poly-L-lysine may be applied to improve construct adherence and minimize contraction. ${ }^{45,46}$

Here we evaluated both the conventional monodispersion format and the proposed multitissue interface culture format on their ability to maintain mechanical boundary conditions and avoid tissue construct contraction (Figure 4). In all of the experiments, the oligomer concentration was kept constant at $1.4 \mathrm{mg} / \mathrm{mL}\left(G^{\prime}=200 \mathrm{~Pa}\right)$ since conventional monodispersion culture of ECFCs within this matrix formulation has been shown to induce robust vessel formation. ${ }^{35}$ The volumes of the sphere ( $5 \mu \mathrm{L} ; \sim 2 \mathrm{~mm}$ in height) and surrounding tissue microenvironment ( $250 \mu \mathrm{L} ; \sim 2.6 \mathrm{~mm}$ in height) were selected such that the tissue sphere was completely embedded within the surrounding tissue microenvironment, ensuring uniform and highly reproducible tissue-tissue interactions and mechanophysical properties across the sphere surface area. As expected, for monodispersion cultures (Figure 4 , top), the tissue construct contraction increased significantly $(p<0.05)$ with increasing cell density, except for constructs prepared at the lowest ECFC density $\left(0.5 \times 10^{6}\right.$ cells $\left./ \mathrm{mL}\right)$, where contraction was not detected. Tissue constructs prepared with $2 \times 10^{6}$ and $5 \times 10^{6}$ cells/mL displayed density-dependent contraction as early as $24 \mathrm{~h}$, with final tissue volume percentages of $38.5 \pm 12.6 \%$ and $10.3 \pm 12.1 \%$, respectively, after 3 days of culture. In contrast, all of the constructs prepared using the multitissue interface method maintained their starting tissue volumes regardless of ECFC seeding density (Figure 4, bottom). Additionally, there was no statistically significant change in the cross-sectional area of the embedded sphere for any of the experimental groups over the 3 day time period (Table S1). Notably, tissue sphere embedment within a surrounding tissue matrix represents a variation of bilayered collagen substrates in which two collagen matrices are polymerized consecutively, one on top of the other. ${ }^{47}$ Both approaches result in fusion of two different tissue microenvironments to create a tissue interface. Unlike the conventional monodispersion format, the multitissue interface approach incorporates a tissue-tissue 
interface that prevents cell-mediated tissue contraction, representing a more controlled and physiologically relevant microenvironment.

As presented here, our in vitro multitissue interface model involves a "tissue spheroid" formed with a specified cell population as well as a specified ECM component. Such an approach should be distinguished from the more well established "cell spheroids", which are formed exclusively from cells. Specifically, endothelial cell spheroids, formed in the absence of any specified matrix component, are routinely embedded within a surrounding collagen matrix, creating an in vitro model of angiogenesis. ${ }^{48}$ Spheroid formation is induced by culturing endothelial cells overnight within nonadherent cultureware. ${ }^{14,49}$ Compared with the multitissue interface model, cell-cell interactions dominate within endothelial cell spheroids, and vasculogenesis is not observed. Instead, vessels sprout and extend from the spheroid into the surrounding matrix, mimicking angiogenesis. ${ }^{48}$

\section{Multitissue Interface Cultures Enhance the Rate and Extent of Vessel Morphogenesis and Stabilization}

In the present study, we compared the two culture formats and observed differences at the tissue and cellular levels in terms of vessel morphogenesis. Although both formats showed that the extent of vessel formation was positively correlated with ECFC density, dramatic differences in vessel network induction, morphology, and stabilization were observed; this is largely attributed to differences in the mechanical boundary conditions (Figure 5). Consistent with our previous reports, ${ }^{35}$ ECFCs cultured for 3 days at low density $\left(0.5 \times 10^{6}\right.$ cells $/ \mathrm{mL}$ ) in a monodispersion format were round or vacuolated with regional collagen type IV deposition associated with ECFC membranes (Figure 5A). As the ECFC density increased, vacuolated cells fused, forming increased numbers of small vessel networks with type IV collagen deposition apparent along the length of the vessel. Constructs containing 5 $\times 10^{6} \mathrm{ECFCs} / \mathrm{mL}$ appeared to have the highest vessel density because of contraction of the tissue volume; however, the ECFCs remained round or formed only short vessels with limited network interconnections (Figure 5A). For monodispersion cultures, the cell-matrix tension balance is quickly lost upon tissue contraction, which occurs when collective cell traction forces overcome tissue-plastic adhesive forces. As such, the matrix-integrincytoskeleton signaling experienced by the vessel-forming endothelial cells is altered, compromising vessel elongation and anastomosis. Clearly, these results confirm that sufficient cell-matrix traction forces are necessary for induction of vasculogenesis as well as vessel morphogenesis. ${ }^{50}$ In addition, the number of vessel-forming networks, which depends on the ECFC density, is an important driver for network connection or anastomosis.

Results observed with the multitissue interface model further support the concept that both the number of vessel-forming networks and cell-matrix traction forces are critical to the overall vessel morphogenesis process. In this format, tissue sphere ECFCs showed rapid, extensive vessel network formation (Figure 5B) that increased with ECFC seeding density. In fact, extensive multicellular vessel networks stabilized by type IV collagen were apparent within only 3 days. This accelerated rate of vessel formation is at least 2 times as fast as those in previous reports by our group ${ }^{35}$ as well as other culture models involving EC- 
pericyte cocultures. ${ }^{19}$ Thus, our model likely better recapitulates in vivo developmental vasculogenesis, which is said to occur in the span of between several hours to a few days. ${ }^{51}$

Upon comparison of the monodispersion and multitissue interface formats at the lowest ECFC density $\left(0.5 \times 10^{6} \mathrm{ECFCs} / \mathrm{mL}\right)$, the observed vessel numbers and morphologies were similar, largely since ECs in the two formats experience similar cell-matrix tension balance. In contrast, high-density multitissue interface cultures prepared with $2 \times 10^{6}$ or $5 \times 10^{6}$ ECFCs $/ \mathrm{mL}$ formed vessel networks that were longer and more interconnected than those in the corresponding monodispersion cultures. We postulate that this improved outcome may be attributed to the fact that the multitissue interface model supports maintenance of the tissue geometry and the associated cell-matrix tensional forces. As shown in Figure 5B, multitissue interface cultures prepared with $5 \times 10^{6} \mathrm{ECFCs} / \mathrm{mL}$ formed extensive, highly interconnected, and lumenized vessel networks (Figure S2) stabilized by a basement membrane, resembling capillary networks formed in vivo. It has been postulated that pericytes or accessory cells are required for stabilization of formed vessels by basement membrane deposition. ${ }^{19}$ However, the results obtained in the present study confirm our previous findings that oligomer collagen matrices are sufficient to induce type IV collagen deposition by ECFCs in the absence of accessory cells, ${ }^{35}$ again emulating steps of vasculogenesis reported in the quail. ${ }^{52}$

\section{Customizable Tissue-Tissue Interface: Addition of ASCs to the Surrounding Tissue Dramatically Improves ECFC Vessel Formation and Stabilization within the Tissue Sphere}

Recently, much attention has been focused on determining how accessory cells, such as pericytes, affect vessel morphogenesis and stabilization for both in vitro and in vivo tissue engineering strategies. ${ }^{38,53-56}$ It is generally accepted that accessory cells enhance vessel morphogenesis through not only paracrine signaling but also direct cell-cell contact. ${ }^{57,58}$ Accessory cells also remodel and reorganize the substrate, which in turn modulates mechanophysical EC-matrix interactions. ${ }^{59}$ To study EC-accessory cell interactions, researchers routinely employ cocultures in which ECs and accessory cells (i.e., pericytes, fibroblasts, ASCs, and bone-marrow-derived mesenchymal stromal cells) are concurrently and homogeneously monodispersed in a substrate. ${ }^{19,39,59}$ In the present study, we employed the multitissue interface model to determine the extent of crosstalk between the two distinct tissue compartments. Specifically, we defined how ECFCs and ASCs, alone or in combination with the surrounding tissue microenvironment, affect ECFC vessel formation within the embedded tissue sphere. For these experiments, all of the tissue constructs were prepared with embedded tissue spheres containing $5 \times 10^{6} \mathrm{ECFCs} / \mathrm{mL}$. ASCs were chosen as the accessory cells because of their suitability for autologous cell therapies.

Qualitative evaluation of constructs cultured for 3 days indicated that ASCs, ECFCs, and ASCs + ECFCs in the surrounding tissue enhanced ECFC vessel formation within the tissue sphere relative to the control containing no accessory cells (Figure 6A-D). Although the quantified vessel volume percentages for the control $(6.4 \pm 2.1 \%)$ and ECFC-only (6.8 $\pm 3.5 \%$ ) groups were statistically similar ( $p>0.05$ ), the ECFC-only group contained fewer quiescent cells and vessels that appeared slightly more elongated. This increase in the percentages of short vessels and small vessel networks and decrease in the percentage of 
quiescent cells were captured by the new algorithm (Figure S1) designed to quantify identified categories of vessel morphology (Figure 6A,B). This quantification strategy provided a vessel morphogenesis "fingerprint" for each experimental group studied.

A dramatic difference was observed in both the volume percentage and morphology of vessels formed when ASCs were added to the surrounding tissue. Both the ASC and ASC + ECFC groups induced the formation of highly interconnected and persistent vessel networks (Figure 6C,D). The vessel volume percentages for the ASC and ASC + ECFC groups were $16.2 \pm 4.7 \%$ and $19.0 \pm 4.5 \%$, respectively, which were more than 2 -fold greater than those without ASCs. In terms of vessel morphology, the ASC and ASC + ECFC groups were composed of $87 \%$ and $85 \%$ extensive vessel networks (EVN), respectively, compared with roughly 50\% EVN for groups without ASCs. Unlike conventional monodispersion cultures, where ECs and accessory cells are cocultured together within a substrate, the multitissue interface model allows ECs and accessory cells to be cocultured in separate but interfacing tissue environments. This approach effectively minimizes the influence of initial direct cellcell contact but allows diffusion of paracrine signals. While an ASC-conditioned medium has been shown in past studies to positively affect EC outgrowth and vessel formation, it did not induce angiogenic vessel sprouting. ${ }^{55,60}$ Similar observations were made in our multitissue interface model, where vascularization was confined within the tissue sphere. Collectively, such findings further suggest that ASC-ECFC crosstalk positively influences vasculogenesis through ASC-mediated paracrine signaling as well as transmission of matrix mechanophysical signals.

\section{Increasing the ASC Density within the Surrounding Tissue of the Multitissue Interface Construct Further Enhances Vascularization within the Tissue Sphere and across the Tissue-Tissue Boundary}

Because enhanced vasculogenesis was observed at a low density of ASCs $\left(0.1 \times 10^{6}\right.$ cells $/ \mathrm{mL}$ ) in the surrounding tissue, we hypothesized that increased ASC density would lead to increased vessel volume percentage within the tissue sphere and also facilitate vessel elongation (angiogenesis) across the tissue interface. Once again, all of the tissue spheres were prepared with $5 \times 10^{6} \mathrm{ECFCs} / \mathrm{mL}$ at a volume of $5 \mu \mathrm{L}$ within $200 \mathrm{~Pa}$ oligomer collagen. After 3 days of culture, enhanced vasculogenesis within the tissue sphere was evident both qualitatively and quantitatively, with an increase in the vessel volume percentage with increasing ASC density (Figure 7A,B). The increase in vessel volume percentage was further correlated to the EVN percentage, with EVN percentages of $80 \%$, $90 \%$, and $94 \%$ for groups containing $0.1 \times 10^{6}, 0.2 \times 10^{6}$, and $0.5 \times 10^{6} \mathrm{ASCs} / \mathrm{mL}$, respectively. Therefore, the extent of vascularization within the tissue sphere was positively correlated with the ASC density in the surrounding tissue. Furthermore, ASCs assumed a pericyte-like role, migrating toward the abluminal wall of the vessels (Figure S3), which is consistent with previous findings in $3 \mathrm{D}$ models using fibrin. ${ }^{58}$

Another interesting finding was the modulation of vascularization events at the tissue-tissue boundary as a function of ASC density. As shown in Figure 7C, when the surrounding tissues were seeded with lower ASC densities $\left(0.1 \times 10^{6}\right.$ and $\left.0.2 \times 10^{6} \mathrm{ASCs} / \mathrm{mL}\right)$, vascularization events were confined primarily to the tissue spheres. However, constructs 
containing $0.5 \times 10^{6} \mathrm{ASCs} / \mathrm{mL}$ showed enhanced vasculogenesis within the sphere as well as vessel elongation or angiogenesis across the tissue interface (Figure 7C). Furthermore, the amount and extent of ASC orientation toward the sphere increased with ASC seeding density (Figure 8). It is well-established that ECFC-secreted platelet-derived growth factor BB (PDGF-BB) is a potent chemoattractant for not only pericytes but also ASCs, ${ }^{61-63}$ making paracrine signaling likely to have contributed to ASC alignment. Another possible contributing factor is mechanotransductive cues. Previous research involving the in vitro EC spheroid model showed that cell traction forces of the EC spheroid radially align collagen fibrils, creating collagen "paths" extending outward from the EC spheroid. ${ }^{49}$ Additionally, EC spheroids showed preferential angiogenic sprouting toward one another even when located 600-800 $\mu \mathrm{m}$ apart. Interestingly their observed long-distance angiogenic sprouting was preceded by matrix reorganization. In our model, we observed increased collagen-fibril alignment or "paths" with increasing ASC density in the surrounding tissue for distances exceeding $1000 \mu \mathrm{m}$ (Figure 8). The distance of ECM alignment was positively correlated with the ASC density in the surrounding tissue. Our current observations combined with those reported in the literature provide evidence that ECFC-ASC crosstalk across tissue boundaries, including cell-matrix mechanophysical forces as well as paracrine signaling, are important vascularization determinants, contributing to both early-stage vasculogenesis and later-stage angiogenesis and vessel elongation.

\section{CONCLUSION}

Vasculogenesis and angiogenesis are dynamic and integrated neovascularization processes that require complex spatiotemporal cell-cell, cell-matrix, and soluble factor signaling. Herein we have described a novel in vitro multitissue interface model that is ideally suited for diverse vascularization studies, including vascularization across tissue-tissue interfaces, because it recapitulates a number of elements associated with in vivo developmental vasculogenesis. Conventional in vitro models focus on vasculogenesis (de novo formation of blood vessels) or angiogenesis (sprouting of vessels from existing vessels or EC monolayers). However, the multitissue interface model captures both initial de novo vasculogenesis within the tissue sphere and later-stage angiogenesis marked by vessel sprouting and elongation into the surrounding tissue compartment. Creating a model with defined and highly reproducible tissue-tissue interfaces involved the application of surfaces with uniquely engineered surface wettability patterns that could capture and support varioussized tissue spheres. Reproducible model development was further facilitated by the use of collagen oligomers, which polymerize rapidly (roughly $10 \mathrm{~min}$ ) and can be formulated to create a broad range of interstitial type I collagen fibril microenvironments (beyond 2000 Pa) ${ }^{26}$ Conventional collagen monomer matrices, even when used at high concentrations, yield compliant matrices with stiffness values of roughly $200 \mathrm{~Pa}$ or less ${ }^{26}$ However, the model shown herein allows control over each tissue microenvironment in terms of matrix composition and physical properties, cell type, and cell density. Importantly, the boundary conditions for the multitissue construct allowed the generation of a component tissue compartment with unprecedented cell densities while avoiding the cell-mediated tissue contraction routinely observed in high-cell-density tissues formed via conventional monodispersion methods. The rapid vasculogenesis observed in the tissue sphere was 
supported by a combination of high cell density and sufficient ECFC-matrix mechanophysical interactions. The stable boundary conditions and microstructure mechanical properties of the collagen-fibril matrix enabled ECFCs to quickly generate the necessary matrix traction force to guide the formation, maturation, and stabilization of vessel networks. Furthermore, the well-documented benefits provided by ASC paracrine signaling were undeniably present in our system; however, it was evident that cell-matrix tensional forces transmitted between tissue compartments also played a role in later-stage angiogenic vessel elongation. While the present work demonstrates the utility of this model for mechanistic studies of tissue and tissue-interface vascularization, the model has broader applications, including bone-soft tissue interactions, tumor-stroma interactions, blood-brain barrier, hematopoietic stem cell niche, and islet-vascular interactions. This novel in vitro model is expected to provide guiding principles for the design of complex multitissue systems, including vascularized tissue-engineered constructs for tissue engineering and regenerative medicine applications.

\section{Supplementary Material}

Refer to Web version on PubMed Central for supplementary material.

\section{Acknowledgments}

This research was supported in part by Grant R01HL10962 (S.L.V.-H. and M.C.Y.) from the National Heart, Lung, and Blood Institute as well as Incentive Grant funds provided by the Purdue University Office of the Executive Vice President for Research and Partnerships (S.L.V.-H.). The content is solely the responsibility of the authors and does not necessarily represent the official views of the National Heart, Lung, and Blood Institute or the National Institutes of Health. This work was also supported by the National Science Foundation. K.P.B. is a recipient of an NSF Graduate Fellowship (DGE-1333468).

\section{References}

1. Mikos AG, Herring SW, Ochareon P, Elisseeff J, Lu HH, Kandel R, Schoen FJ, Toner M, Mooney D, Atala A, Van Dyke ME, Kaplan D, Vunjak-Novakovic G. Engineering Complex Tissues. Tissue Eng. 2006; 12:3307-3339. [PubMed: 17518671]

2. Lu HH, Jiang J. Interface Tissue Engineering and the Formulation of Multiple-tissue systems. Adv Biochem Eng Biotechnol. 2006; 102:91-111. [PubMed: 17089787]

3. Phillips JE, Burns KL, Le Doux JM, Guldberg RE, Garcia AJ. Engineering Graded Tissue Interfaces. Proc Natl Acad Sci USA. 2008; 105:12170-12175. [PubMed: 18719120]

4. Lovett M, Lee K, Edwards A, Kaplan DL. Vascularization Strategies for Tissue Engineering. Tissue Eng, Part B. 2009; 15:353-370.

5. Mammoto T, Mammoto A, Ingber DE. Mechanobiology and Developmental Control. Annu Rev Cell Dev Biol. 2013; 29:27-61. [PubMed: 24099083]

6. Risau W, Flamme I. Vasculogenesis. Annu Rev Cell Dev Biol. 1995; 11:73-91. [PubMed: 8689573]

7. Patel-Hett S, D’Amore PA. Signal Transduction in Vasculogenesis and Developmental Angiogenesis. Int J Dev Biol. 2011; 55:353-363. [PubMed: 21732275]

8. Montesano R, Orci L. Tumor-promoting Phorbol Esters Induce Angiogenesis In Vitro. Cell. 1985; 42:469-477. [PubMed: 2411423]

9. Chalupowicz DG, Chowdhury ZA, Bach TL, Barsigian C, Martinez J. Fibrin II Induces Endothelial Cell Capillary Tube Formation. J Cell Biol. 1995; 130:207-215. [PubMed: 7540617]

10. Montesano R, Orci L, Vassalli P. In Vitro Rapid Organization of Endothelial Cells into Capillarylike Networks is Promoted by Collagen Matrices. J Cell Biol. 1983; 97:1648-1652. [PubMed: 6630296] 
11. Nicosia RF, Ottinetti A. Growth of Microvessels in Serum-free Matrix Culture of Rat Aorta. A Quantitative Assay of Angiogenesis In Vitro. Lab Invest. 1990; 63:115-122. [PubMed: 1695694]

12. Hoying JB, Williams SK. Effects of Basic Fibroblast Growth Factor on Human Microvessel Endothelial Cell Migration on Collagen I Correlates Inversely with Adhesion and Is Cell Density Dependent. J Cell Physiol. 1996; 168:294-304. [PubMed: 8707865]

13. Nehls V, Drenckhahn D. A Microcarrier-based Cocultivation System for the Investigation of Factors and Cells Involved in Angiogenesis in Three-dimensional Fibrin Matrices In Vitro. Histochem Cell Biol. 1995; 104:459-466. [PubMed: 8777732]

14. Korff T, Augustin HG. Integration of Endothelial Cells in Multicellular Spheroids Prevents Apoptosis and Induces Differentiation. J Cell Biol. 1998; 143:1341-1352. [PubMed: 9832561]

15. Pepper MS, Montesano R, Vassalli JD, Orci L. Chondrocytes Inhibit Endothelial Sprout Formation In Vitro: Evidence for Involvement of a Transforming Growth Factor-Beta. J Cell Physiol. 1991; 146:170-179. [PubMed: 1703548]

16. Vailhe B, Vittet D, Feige JJ. In Vitro Models of Vasculogenesis and Angiogenesis. Lab Invest. 2001; 81:439-452. [PubMed: 11304563]

17. Madri JA, Pratt BM, Tucker AM. Phenotypic Modulation of Endothelial Cells by Transforming Growth Factor-Beta Depends Upon the Composition and Organization of the Extracellular Matrix. J Cell Biol. 1988; 106:1375-1384. [PubMed: 3283153]

18. Bayless KJ, Salazar R, Davis GE. RGD-dependent Vacuolation and Lumen Formation Observed During Endothelial Cell Morphogenesis in Three-dimensional Fibrin Matrices Involves the Alpha(v)Beta(3) and Alpha(5)Beta(1) Integrins. Am J Pathol. 2000; 156:1673-1683. [PubMed: 10793078]

19. Saunders WB, Bohnsack BL, Faske JB, Anthis NJ, Bayless KJ, Hirschi KK, Davis GE. Coregulation of Vascular Tube Stabilization by Endothelial Cell TIMP-2 and Pericyte TIMP-3. J Cell Biol. 2006; 175:179-191. [PubMed: 17030988]

20. Davis GE, Bayless KJ, Mavila A. Molecular Basis of Endothelial Cell Morphogenesis in Threedimensional Extracellular Matrices. Anat Rec. 2002; 268:252-275. [PubMed: 12382323]

21. Sieminski AL, Hebbel RP, Gooch KJ. The Relative Magnitudes of Endothelial Force Generation and Matrix Stiffness Modulate Capillary Morphogenesis In Vitro. Exp Cell Res. 2004; 297:574584. [PubMed: 15212957]

22. Edgar LT, Hoying JB, Weiss JA. In Silico Investigation of Angiogenesis with Growth and Stress Generation Coupled to Local Extracellular Matrix Density. Ann Biomed Eng. 2015; 43:15311542. [PubMed: 25994280]

23. Krishnan L, Underwood CJ, Maas S, Ellis BJ, Kode TC, Hoying JB, Weiss JA. Effect of Mechanical Boundary Conditions on Orientation of Angiogenic Microvessels. Cardiovasc Res. 2008; 78:324-332. [PubMed: 18310100]

24. Jain RK, Au P, Tam J, Duda DG, Fukumura D. Engineering Vascularized Tissue. Nat Biotechnol. 2005; 23:821-823. [PubMed: 16003365]

25. Kreger ST, Bell BJ, Bailey J, Stites E, Kuske J, Waisner B, Voytik-Harbin SL. Polymerization and Matrix Physical Properties as Important Design Considerations for Soluble Collagen Formulations. Biopolymers. 2010; 93:690-707. [PubMed: 20235198]

26. Bailey JL, Critser PJ, Whittington C, Kuske JL, Yoder MC, Voytik-Harbin SL. Collagen Oligomers Modulate Physical and Biological Properties of Three-dimensional Self-assembled Matrices. Biopolymers. 2011; 95:77-93. [PubMed: 20740490]

27. Whittington CF, Brandner E, Teo KY, Han B, Nauman E, Voytik-Harbin SL. Oligomers Modulate Interfibril Branching and Mass Transport Properties of Collagen Matrices. Microsc Microanal. 2013; 19:1323-1333. [PubMed: 23842082]

28. Voytik-Harbin, SL.; Han, B. Collagen-Cell Interactions and Modeling in Microenvironments. In: Neu, CP.; Genin, G., editors. CRC Handbook of Imaging in Biological Mechanics. Taylor \& Francis Group; Boca Raton, FL: 2015. p. 261-273.

29. Critser PJ, Kreger ST, Voytik-Harbin SL, Yoder MC. Collagen Matrix Physical Properties Modulate Endothelial Colony Forming Cell-derived Vessels In Vivo. Microvasc Res. 2010; 80:2330. [PubMed: 20219180] 
30. Chen X, Patel RS, Weibel JA, Garimella SV. Coalescence-Induced Jumping of Multiple Condensate Droplets on Hierarchical Superhydrophobic Surfaces. Sci Rep. 2016; 6:18649. [PubMed: 26725512]

31. ASTM Standard F3089: Characterization and Standardization of Polymerizable Collagen-Based Products and Associated Collagen-Cell Interactions. ASTM International; West Conshohocken, PA: 2014. www.astm.org

32. Roeder BA, Kokini K, Sturgis JE, Robinson JP, Voytik-Harbin SL. Tensile Mechanical Properties of Three-dimensional Type I Collagen Extracellular Matrices with Varied Microstructure. J Biomech Eng. 2002; 124:214-222. [PubMed: 12002131]

33. Ingram DA, Mead LE, Tanaka H, Meade V, Fenoglio A, Mortell K, Pollok K, Ferkowicz MJ, Gilley D, Yoder MC. Identification of a Novel Hierarchy of Endothelial Progenitor Cells Using Human Peripheral and Umbilical Cord Blood. Blood. 2004; 104:2752-2760. [PubMed: 15226175]

34. Voytik-Harbin SL, Rajwa B, Robinson JP. Three-dimensional Imaging of Extracellular Matrix and Extracellular Matrix-Cell Interactions. Methods Cell Biol. 2001; 63:583-597. [PubMed: 11060860]

35. Whittington CF, Yoder MC, Voytik-Harbin SL. Collagen-polymer Guidance of Vessel Network Formation and Stabilization by Endothelial Colony Forming Cells In Vitro. Macromol Biosci. 2013; 13:1135-1149. [PubMed: 23832790]

36. Davis GE, Camarillo CW. An Alpha 2 Beta 1 Integrin-dependent Pinocytic Mechanism Involving Intracellular Vacuole Formation and Coalescence Regulates Capillary Lumen and Tube Formation in Three-dimensional Collagen Matrix. Exp Cell Res. 1996; 224:39-51. [PubMed: 8612690]

37. Stratman AN, Saunders WB, Sacharidou A, Koh W, Fisher KE, Zawieja DC, Davis MJ, Davis GE. Endothelial Cell Lumen and Vascular Guidance Tunnel Formation Requires MT1-MMPdependent Proteolysis in 3-Dimensional Collagen Matrices. Blood. 2009; 114:237-247. [PubMed: 19339693]

38. Allen P, Melero-Martin J, Bischoff J. Type I Collagen, Fibrin and PuraMatrix Matrices Provide Permissive Environments for Human Endothelial and Mesenchymal Progenitor Cells to Form Neovascular Networks. J Tissue Eng Regener Med. 2011; 5:e74-86.

39. Rao RR, Peterson AW, Ceccarelli J, Putnam AJ, Stegemann JP. Matrix Composition Regulates Three-dimensional Network Formation by Endothelial Cells and Mesenchymal Stem Cells in Collagen/Fibrin Materials. Angiogenesis. 2012; 15:253-264. [PubMed: 22382584]

40. Koh W, Stratman AN, Sacharidou A, Davis GE. In Vitro Three Dimensional Collagen Matrix Models of Endothelial Lumen Formation During Vasculogenesis and Angiogenesis. Methods Enzymol. 2008; 443:83-101. [PubMed: 18772012]

41. Whisler JA, Chen MB, Kamm RD. Control of Perfusable Microvascular Network Morphology Using a Multiculture Microfluidic System. Tissue Eng, Part C. 2014; 20:543-552.

42. Vernon RB, Sage EH. Contraction of Fibrillar Type I Collagen by Endothelial Cells: a Study In Vitro. J Cell Biochem. 1996; 60:185-197. [PubMed: 8655629]

43. Mohammadi H, Arora PD, Simmons CA, Janmey PA, McCulloch CA. Inelastic Behaviour of Collagen Networks in Cell-Matrix Interactions and Mechanosensation. JR Soc, Interface. 2015; 12:20141074.

44. Park YK, Tu TY, Lim SH, Clement IJ, Yang SY, Kamm RD. Microvessel Growth and Remodeling within a Three-dimensional Microfluidic Environment. Cell Mol Bioeng. 2014; 7:15-25. [PubMed: 24660039]

45. Cross VL, Zheng Y, Won Choi N, Verbridge SS, Sutermaster BA, Bonassar LJ, Fischbach C, Stroock AD. Dense Type I Collagen Matrices that Support Cellular Remodeling and Microfabrication for Studies of Tumor Angiogenesis and Vasculogenesis In Vitro. Biomaterials. 2010; 31:8596-8607. [PubMed: 20727585]

46. Morgan JP, Delnero PF, Zheng Y, Verbridge SS, Chen J, Craven M, Choi NW, Diaz-Santana A, Kermani P, Hempstead B, Lopez JA, Corso TN, Fischbach C, Stroock AD. Formation of Microvascular Networks In Vitro. Nat Protoc. 2013; 8:1820-1836. [PubMed: 23989676]

47. Sorrell JM, Baber MA, Caplan AI. Construction of a Bilayered Dermal Equivalent Containing Human Papillary and Reticular Dermal Fibroblasts: Use of Fluorescent Vital Dyes. Tissue Eng. 1996; 2:39-49. [PubMed: 19877950] 
48. Heiss M, Hellstrom M, Kalen M, May T, Weber H, Hecker M, Augustin HG, Korff T. Endothelial Cell Spheroids as a Versatile Tool to Study Angiogenesis In Vitro. FASEB J. 2015; 29:3076-3084. [PubMed: 25857554]

49. Korff T, Augustin HG. Tensional Forces in Fibrillar Extracellular Matrices Control Directional Capillary Sprouting. J Cell Sci. 1999; 112:3249-3258. [PubMed: 10504330]

50. Ingber DE. Mechanical Signaling and the Cellular Response to Extracellular Matrix in Angiogenesis and Cardiovascular Physiology. Circ Res. 2002; 91:877-887. [PubMed: 12433832]

51. Drake CJ. Embryonic and Adult Vasculogenesis. Birth Defects Res, Part C. 2003; 69:73-82.

52. Drake CJ, LaRue A, Ferrara N, Little CD. VEGF Regulates Cell Behavior During Vasculogenesis. Dev Biol. 2000; 224:178-188. [PubMed: 10926758]

53. Traktuev DO, Prater DN, Merfeld-Clauss S, Sanjeevaiah AR, Saadatzadeh MR, Murphy M, Johnstone BH, Ingram DA, March KL. Robust Functional Vascular Network Formation In Vivo by Cooperation of Adipose Progenitor and Endothelial Cells. Circ Res. 2009; 104:1410-1420. [PubMed: 19443841]

54. Au P, Tam J, Fukumura D, Jain RK. Bone Marrow-derived Mesenchymal Stem Cells Facilitate Engineering of Long-lasting Functional Vasculature. Blood. 2008; 111:4551-4558. [PubMed: 18256324]

55. Rohringer S, Hofbauer P, Schneider KH, Husa AM, Feichtinger G, Peterbauer-Scherb A, Redl H, Holnthoner W. Mechanisms of Vasculogenesis in 3D Fibrin Matrices Mediated by the Interaction of Adipose-derived Stem Cells and Endothelial Cells. Angiogenesis. 2014; 17:921-933. [PubMed: 25086616]

56. Strassburg S, Nienhueser H, Bjorn Stark G, Finkenzeller G, Torio-Padron N. Co-culture of Adipose-derived Stem Cells and Endothelial Cells in Fibrin Induces Angiogenesis and Vasculogenesis in a Chorioallantoic Membrane Model. J Tissue Eng Regener Med. 2013; doi: 10.1002/term. 1769

57. Stratman AN, Davis MJ, Davis GE. VEGF and FGF Prime Vascular Tube Morphogenesis and Sprouting Directed by Hematopoietic Stem Cell Cytokines. Blood. 2011; 117:3709-3719. [PubMed: 21239704]

58. Pill K, Hofmann S, Redl H, Holnthoner W. Vascularization Mediated by Mesenchymal Stem Cells from Bone Marrow and Adipose Tissue: a Comparison. Cell Regener. 2015; 4:8.

59. Holnthoner W, Hohenegger K, Husa AM, Muehleder S, Meinl A, Peterbauer-Scherb A, Redl H. Adipose-derived Stem Cells Induce Vascular Tube Formation of Outgrowth Endothelial Cells in a Fibrin Matrix. J Tissue Eng Regener Med. 2015; 9:127-136.

60. Verseijden F, Posthumus-van Sluijs SJ, Pavljasevic P, Hofer SO, van Osch GJ, Farrell E. Adult Human Bone Marrow- and Adipose Tissue-derived Stromal Cells Support the Formation of Prevascular-like Structures from Endothelial Cells In Vitro. Tissue Eng, Part A. 2010; 16:101-114. [PubMed: 19642855]

61. Hellstrom M, Kalen M, Lindahl P, Abramsson A, Betsholtz C. Role of PDGF-B and PDGFR-beta in Recruitment of Vascular Smooth Muscle Cells and Pericytes during embryonic blood vessel formation in the mouse. Development. 1999; 126:3047-3055. [PubMed: 10375497]

62. Stratman AN, Schwindt AE, Malotte KM, Davis GE. Endothelial-derived PDGF-BB and HB-EGF Coordinately Regulate Pericyte Recruitment During Vasculogenic Tube Assembly and Stabilization. Blood. 2010; 116:4720-4730. [PubMed: 20739660]

63. Gehmert S, Gehmert S, Hidayat M, Sultan M, Berner A, Klein S, Zellner J, Muller M, Prantl L. Angiogenesis: the Role of PDGF-BB on Adipose-tissue Derived Stem Cells (ASCs). Clin Hemorheol Microcirc. 2011; 48:5-13. [PubMed: 21876230] 


\section{CULTURE METHOD}

A Mono-dispersion

Mono-dispersion of cells within collagen-fibril matrix

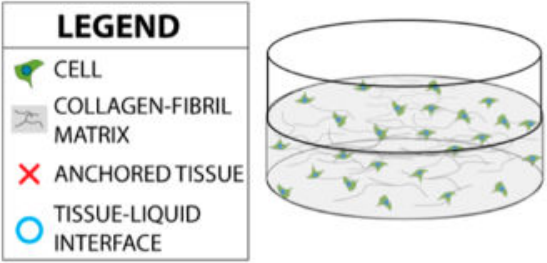

\section{BOUNDARY CONDITIONS}

B

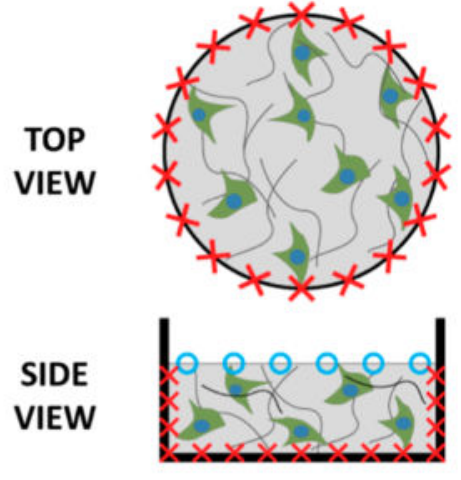

D

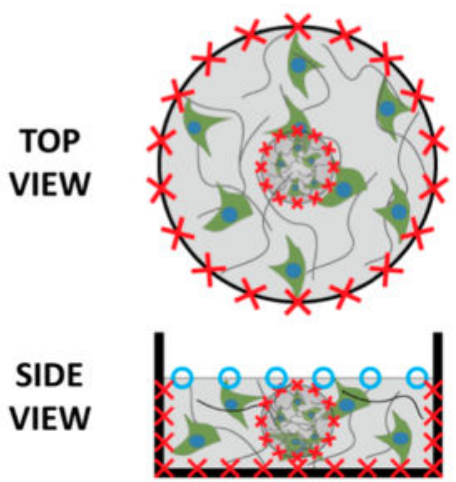

Figure 1.

$(\mathrm{A}, \mathrm{C})$ Schematic diagrams and $(\mathrm{B}, \mathrm{D})$ boundary conditions for $(\mathrm{A}, \mathrm{B})$ homogeneous monodispersion and (C, D) multitissue interface culture formats. Monodispersion cultures involve homogeneous distribution of cells within a surrounding collagen-fibril matrix. Multitissue interface cultures are created by embedding a cell-collagen tissue sphere within a surrounding cell-collagen tissue construct. 


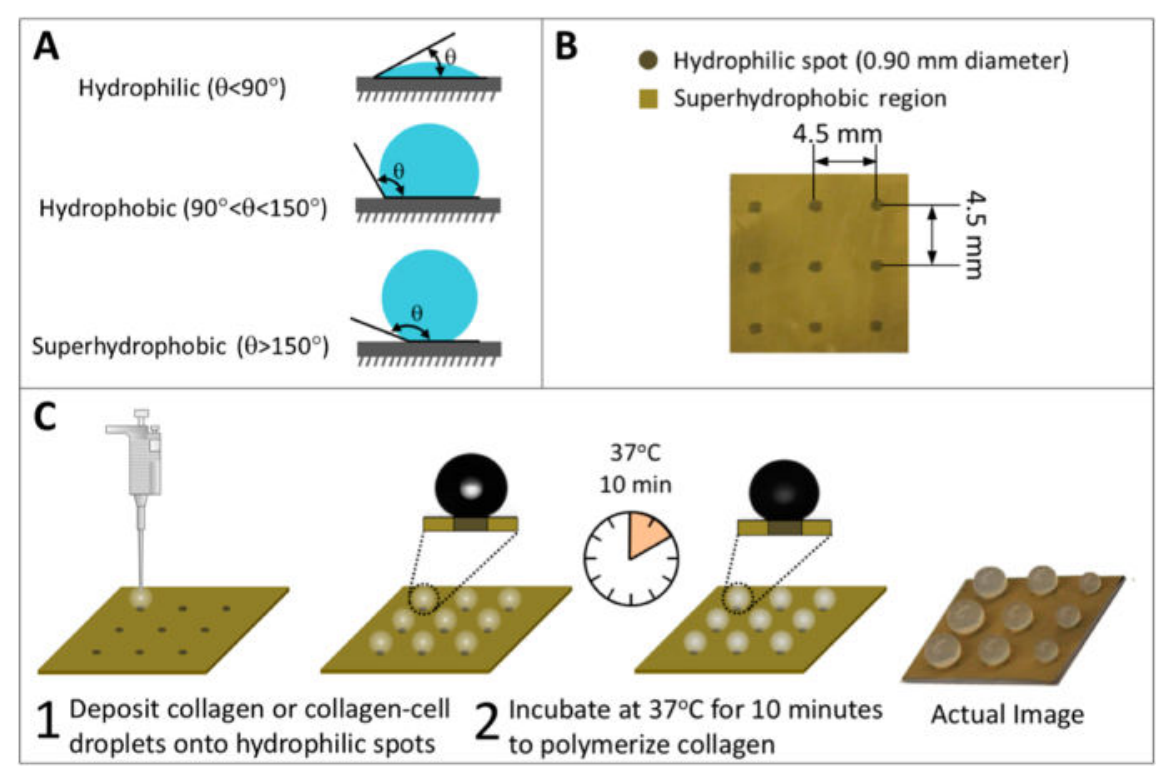

Figure 2.

(A) Schematic diagram demonstrating interactions of a droplet with surfaces having uniform wetting properties. (B) Biphilic surfaces with hydrophilic spots surrounded by superhydrophobic regions used to form collagen or tissue spheres. The superhydrophobic areas facilitate sphere formation, while the hydrophilic spots assist in deposition and adhesion of spheres to the substrate. (C) Overview of the tissue sphere formation process. Aliquots of neutralized oligomer solution in the presence or absence of cells are deposited onto the hydrophilic spots of the biphilic surface. The surface is subsequently placed into a humidified $37^{\circ} \mathrm{C}$ incubator to induce self-assembly of collagen fibrils (polymerization). The rightmost photograph shows oligomer collagen spheres with volumes of 15,10 , and $5 \mu \mathrm{L}$ formed on the biphilic surface. 


\begin{tabular}{|c|c|c|c|c|c|c|c|c|c|c|c|c|}
\hline A & \multicolumn{9}{|c|}{$10 \mu \mathrm{L}$} & \multicolumn{3}{c|}{10} \\
\hline
\end{tabular}

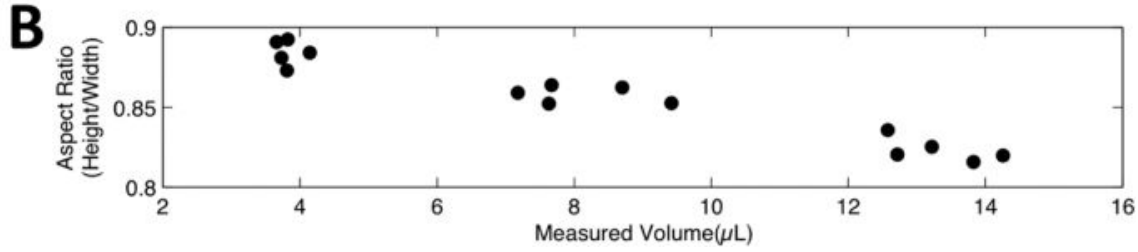

Figure 3.

(A) Representative goniometer images and volumetric measurements for oligomer spheres prepared at target volumes of 5,10 , and $15 \mu \mathrm{L}$ with matrix stiffnesses of 0 (water), 200, and $1000 \mathrm{~Pa}$ (specified by the oligomer concentration). The goniometer images represent oligomer spheres $(200 \mathrm{~Pa})$ prepared at designated volumes (scale bar $=1 \mathrm{~mm})$. Target volume indicates the volume specified on the air-displacement (Air) or positivedisplacement (Pos) micropipette. (B) Scatter plot of measured oligomer sphere volumes and aspect ratios for all of the matrix stiffness values. Data points represent a combination of 0 , 200, and $1000 \mathrm{~Pa}$ oligomer spheres. 


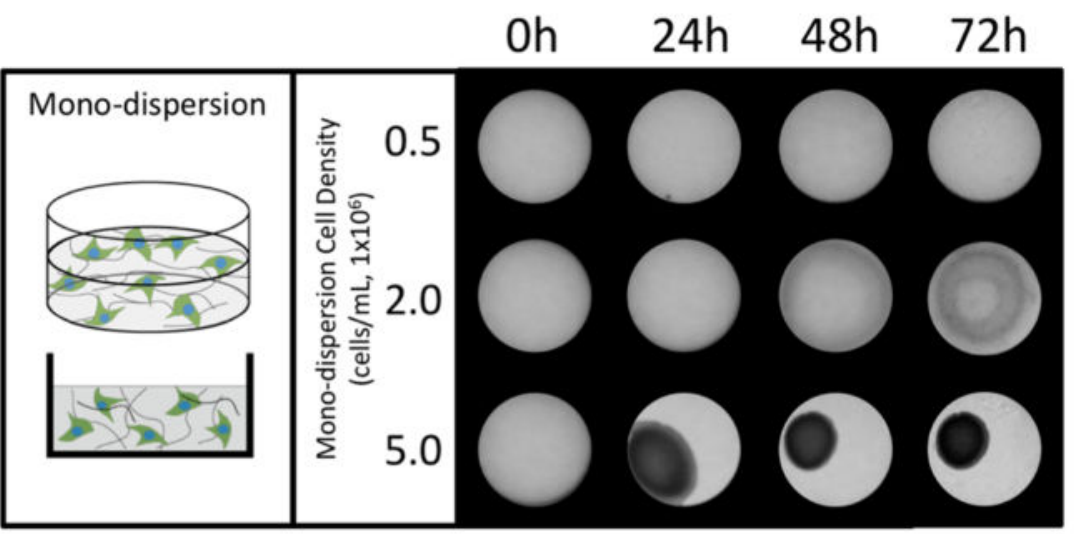

Final Tissue Tukey Volume (\%) Group

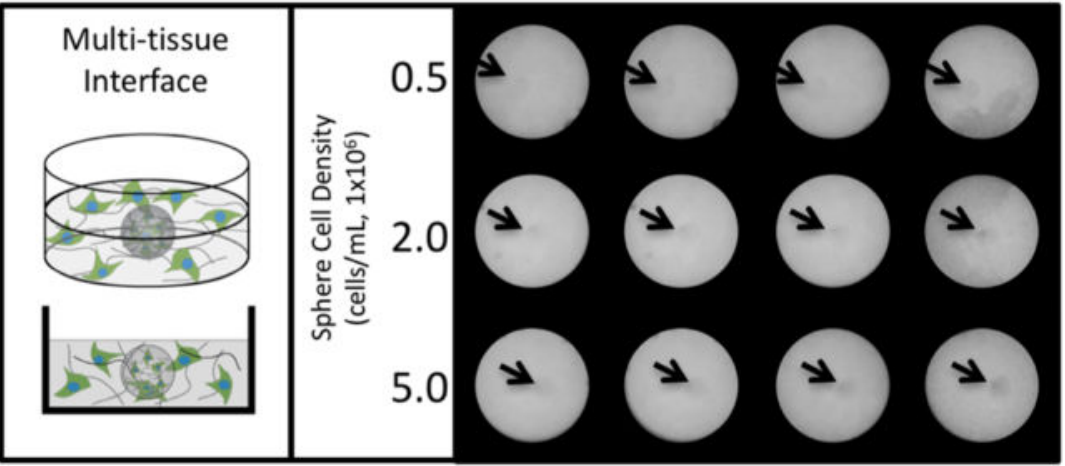

$98.1 \%$

$\pm 1.4 \%$

A

$102.3 \%$

$\pm 7.9 \%$

A

$99.7 \%$

$\pm 8.3 \%$

A

Figure 4.

Time-dependent contraction of tissue constructs prepared using (top) the monodispersion format and (bottom) the multitissue interface method. Monodispersion constructs were prepared by seeding $0.5 \times 10^{6}, 2.0 \times 10^{6}$, or $5.0 \times 10^{6} \mathrm{ECFCs} / \mathrm{mL}$ within an oligomer matrix $(200 \mathrm{~Pa})$. Multitissue interface constructs involved embedding an oligomer sphere (200 Pa, 5 $\mu \mathrm{L}$; arrows) prepared with $0.5 \times 10^{6}, 2.0 \times 10^{6}$, or $5.0 \times 10^{6} \mathrm{ECFCs} / \mathrm{mL}$ within a surrounding tissue consisting of $0.5 \times 10^{6} \mathrm{ECFCs} / \mathrm{mL}$ within an oligomer matrix (200 Pa). Final tissue volumes were measured after $72 \mathrm{~h}$ of culture and compared statistically using Tukey's test. Letters indicate statistically different groups $(p<0.05)$. 


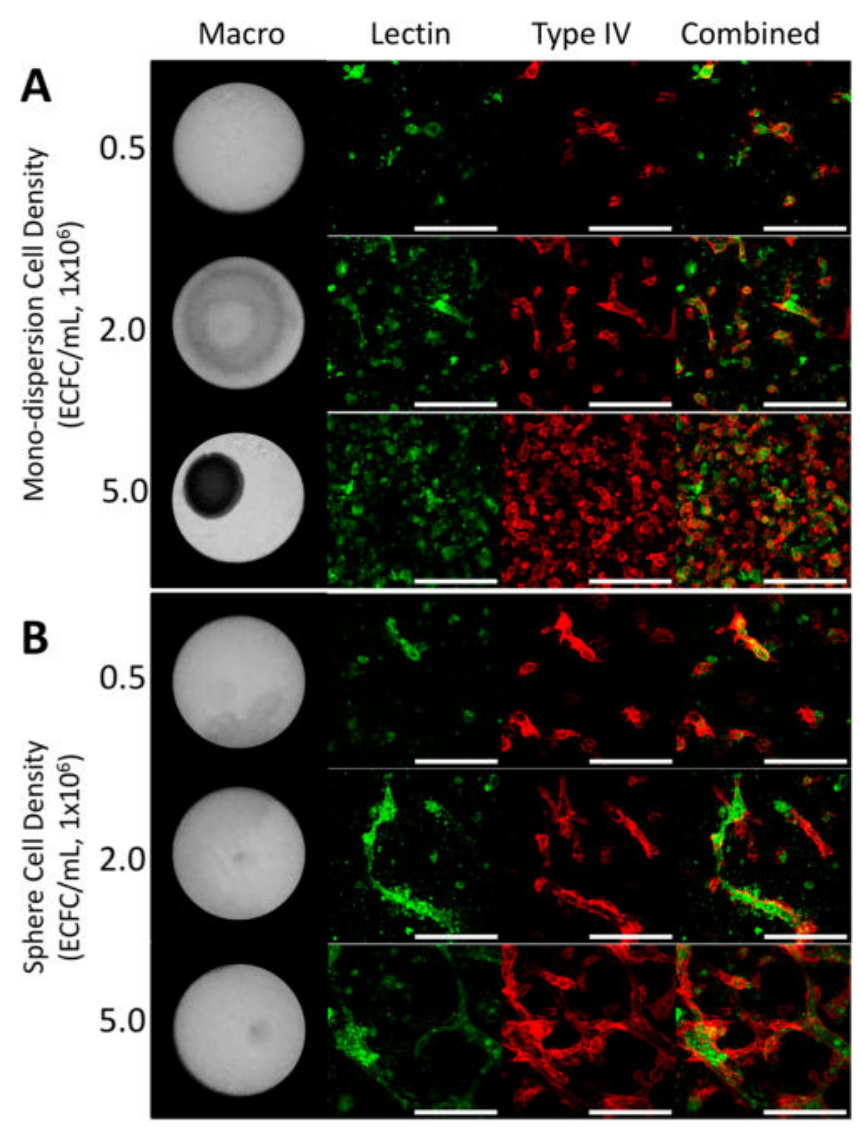

Figure 5.

Projections of confocal image stacks ( $50 \mu \mathrm{m}$ thick) illustrating vessel network formation (green fluorescence, lectin) and type IV collagen deposition (red fluorescence) following 3 days of culture in either (A) the monodispersion format or (B) the multitissue interface format. Confocal images were taken within the tissue sphere of the multitissue interface format. Monodispersion constructs were prepared by seeding ECFCs at specified densities within an oligomer matrix (200 $\mathrm{Pa}, 250 \mu \mathrm{L})$. Multitissue interface constructs were prepared by embedding an oligomer sphere (200 $\mathrm{Pa}, 5 \mu \mathrm{L})$ prepared with ECFCs at a specified density within a surrounding tissue consisting of $0.5 \times 10^{6} \mathrm{ECFCs} / \mathrm{mL}$ within an oligomer matrix (200 Pa, $250 \mu \mathrm{L}$ ). After 3 days of culture, the $5 \times 10^{6} \mathrm{ECFCs} / \mathrm{mL}$ sphere demonstrated superior vessel network formation relative to the other groups. Scale bars $=150 \mu \mathrm{m}$. 


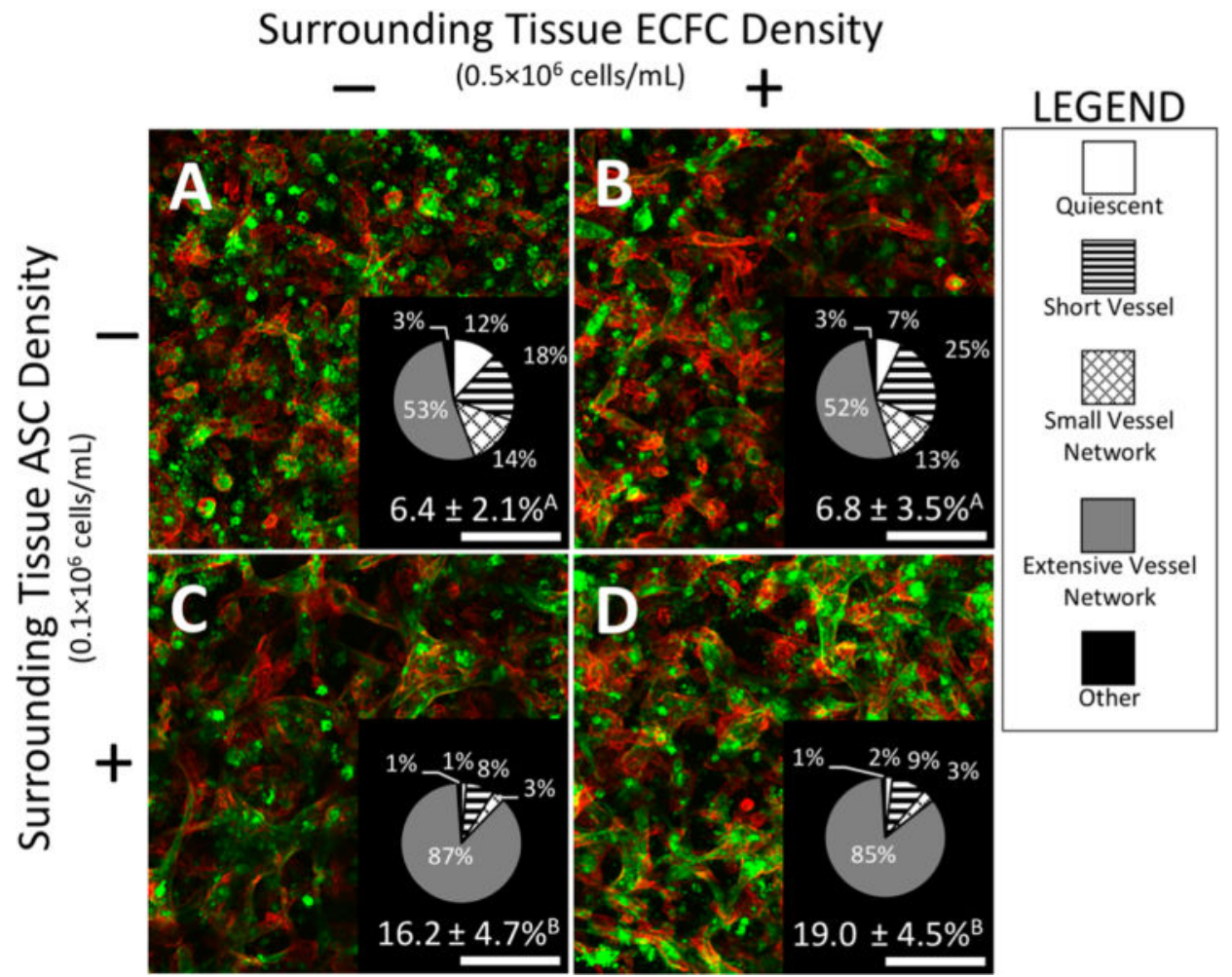

Figure 6.

Projections of confocal image stacks (200 $\mu \mathrm{m}$ thick) taken within the tissue sphere, illustrating vessel network formation and basement membrane deposition for various multitissue interface constructs after 3 days of culture. ECFC-encapsulated oligomer spheres (200 Pa, $5 \times 10^{6} \mathrm{ECFCs} / \mathrm{mL}, 5 \mu \mathrm{L}$ ) were embedded in oligomer matrices (200 Pa, $250 \mu \mathrm{L}$ ) seeded with either (A) no accessory cells, (B) ECFCs only, (C) ASCs only, or (D) a combination of ECFCs and ASCs. Tissue constructs were stained with UEA1 lectin (green fluorescence) and type IV collagen (red fluorescence) for visualization of ECFC vessel networks and deposited basement membrane, respectively. The inset at the bottom right in each panel contains quantified vessel morphology parameters and vessel volume percentages. The vessel volume percentage increased significantly with the presence of ASCs in the surrounding tissue, as determined using Tukey's test. Superscript letters indicate statistically different groups $(p<0.05)$. Scale bars $=150 \mu \mathrm{m}$. 


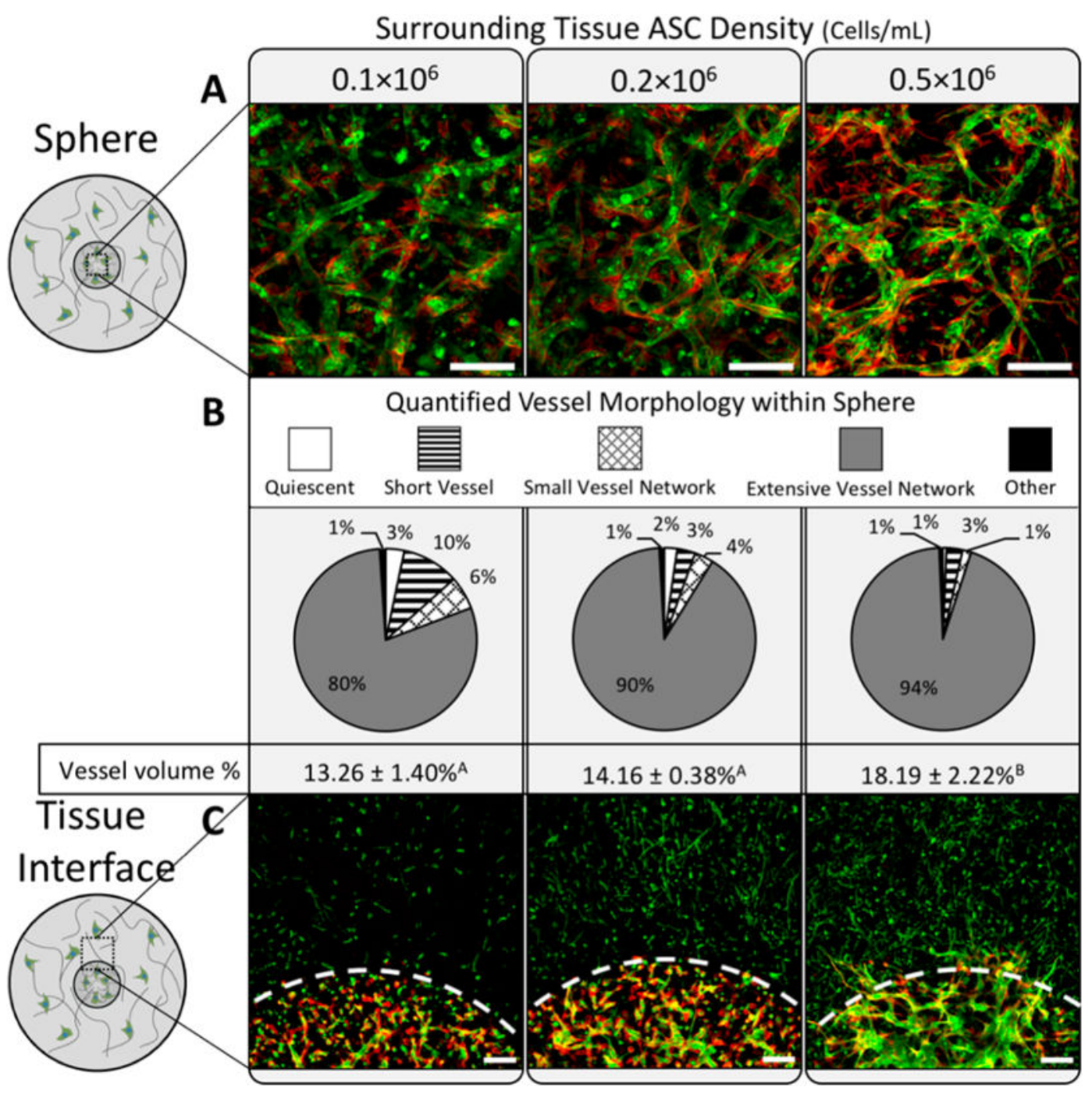

Figure 7.

(A) Projections of confocal image stacks (200 $\mu$ m thick) illustrating vessel network formation and basement membrane deposition within the tissue sphere for various multitissue interface constructs after 3 days of culture. ECFC-encapsulated oligomer spheres $\left(200 \mathrm{~Pa}, 5 \times 10^{6} \mathrm{ECFCs} / \mathrm{mL}, 5 \mu \mathrm{L}\right)$ were embedded in oligomer matrices $(200 \mathrm{~Pa}, 250 \mu \mathrm{L})$ seeded with ASCs at either $0.1 \times 10^{6}, 0.2 \times 10^{6}$, or $0.5 \times 10^{6}$ cells $/ \mathrm{mL}$. Tissue constructs were stained with UEA1 lectin (green fluorescence) and anti-type IV collagen (red fluorescence) for visualization of ECFC vessel networks and deposited basement membrane, respectively. Scale bars $=150 \mu \mathrm{m}$. (B) Quantified vessel morphology parameters show that the vessel volume percentage as well as the percentage of extensive vessel networks were positively correlated with the ASC density. Tukey's test was used to compare groups. Superscript letters indicate statistically different groups $(p<0.05)$. (C) Projection of confocal image stacks ( $50 \mu \mathrm{m}$ thick) illustrating vessel network formation at and across the tissue-tissue interface (dotted line). Tissue constructs were stained with phalloidin (green fluorescence) and anti-type IV collagen (red fluorescence) for visualization of cells and deposited basement membrane, respectively. Scale bars $=150 \mu \mathrm{m}$. 


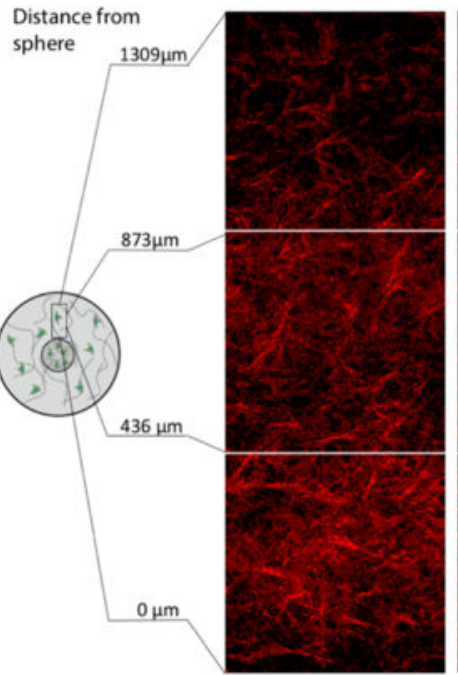

Group

Sphere

Surrounding

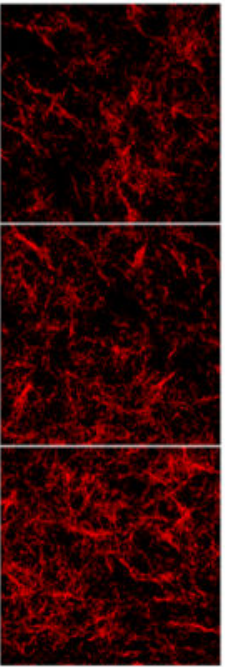

B $5 \times 10^{6} \mathrm{ECFC} / \mathrm{mL}$

Acellular

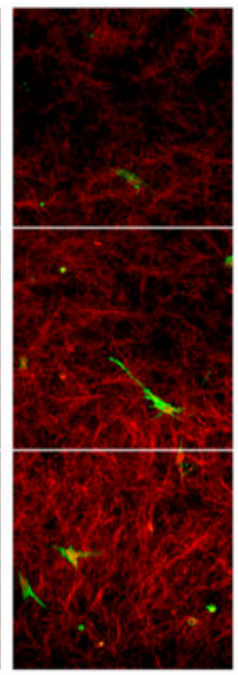

C

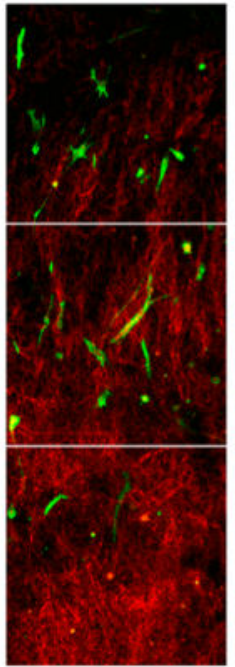

D

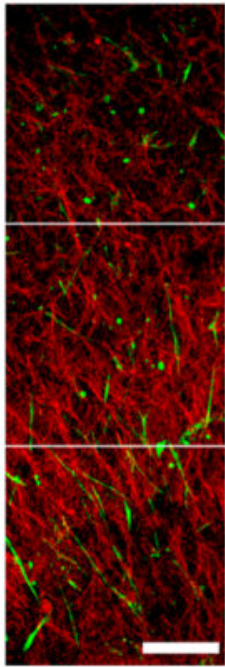

E

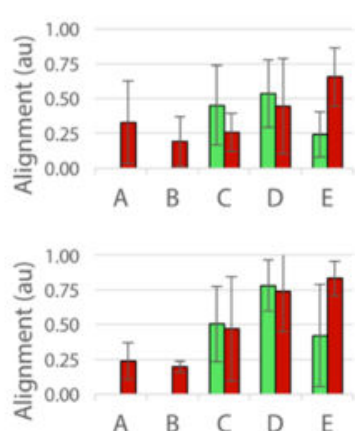

$5 \times 10^{6} \mathrm{ECFC} / \mathrm{mL} \quad 5 \times 10^{6} \mathrm{ECFC} / \mathrm{mL} \quad 5 \times 10^{6} \mathrm{ECFC} / \mathrm{mL}$ $0.1 \times 10^{6} \mathrm{ASC} / \mathrm{mL} \quad 0.2 \times 10^{6} \mathrm{ASC} / \mathrm{mL} \quad 0.5 \times 10^{6} \mathrm{ASC} / \mathrm{mL}$

Figure 8.

(left) Schematic showing imaging areas with specified distances from the sphere. (center) Projections of confocal image stacks ( $30 \mu \mathrm{m}$ thick) outside the tissue sphere for various multitissue interface constructs after 3 days of culture. ECFC-encapsulated oligomer spheres (200 Pa, acellular or $5 \times 10^{6} \mathrm{ECFCs} / \mathrm{mL}, 5 \mu \mathrm{L}$ ) were embedded in oligomer matrices (200 $\mathrm{Pa}, 250 \mu \mathrm{L})$ seeded with ASCs at either $0.0 \times 10^{6}, 0.1 \times 10^{6}, 0.2 \times 10^{6}$, or $0.5 \times 10^{6}$ cells/mL. Tissue constructs were stained with phalloidin (green fluorescence) for visualization of ASC orientation, and confocal reflectance was used to visualize the collagen-fibril microstructure (red fluorescence). Increasing the ASC density in the surrounding tissue increases the collective cell-mediated traction force, leading to tensioninduced alignment of collagen fibrils. Parallel alignment of collagen fibrils appears to be positively correlated with the ASC seeding density. Constructs with $0.5 \times 10^{6} \mathrm{ASCs} / \mathrm{mL}$ yielded higher alignment at distances farther away from the sphere compared with the other groups. Scale bar $=150 \mu \mathrm{m}$. (right) Bar graphs displaying the alignment of the collagen fibrils (red) and ASCs (green) for each respective group. 